\begin{tabular}{|l|l|l||}
\hline \multicolumn{2}{|c|}{ PublisherInfo } \\
\hline \hline PublisherName & $:$ & BioMed Central \\
\hline \hline PublisherLocation & $:$ & London \\
\hline \hline PublisherImprintName & $:$ & BioMed Central \\
\hline \hline
\end{tabular}

\title{
Strength in numbers
}

\begin{tabular}{|l|l|l||}
\hline \multicolumn{2}{|c|}{ ArticleInfo } \\
\hline \hline ArticleID & $:$ & 4621 \\
\hline \hline ArticleDOI & $:$ & $10.1186 /$ gb-spotlight-20021028-01 \\
\hline \hline ArticleCitationID & $:$ & spotlight-20021028-01 \\
\hline \hline ArticleSequenceNumber & $:$ & 287 \\
\hline \hline ArticleCategory & $:$ & Research news \\
\hline \hline ArticleFirstPage & $:$ & 1 \\
\hline \hline ArticleLastPage & $:$ & 3 \\
\hline \hline & & RegistrationDate : 2002-10-28 \\
ArticleHistory & $:$ & OnlineDate $\quad$ 2002-10-28 \\
\hline \hline ArticleCopyright & $:$ & BioMed Central Ltd2002 \\
\hline \hline ArticleGrants & $:$ & \\
\hline \hline ArticleContext & $:$ & 130593311 \\
\hline \hline
\end{tabular}


Although they are an ocean apart, Canada and the Netherlands have found common scientific ground. Genome Canada and the Netherlands Genomics Initiativesigned an agreement October 15 to join forces on large-scale genomics projects. The two-and-a-half year deal is intended to promote exchanges between the countries' academic scientists, as well as build bridges between biotech and large drug companies, said Anie Perrault, vice president of communications for Genome Canada in Ottawa.

Sharing discoveries and partnering to help find and fund research on larger and more difficult genomics projects will maximize both countries' existing strengths, Perrault noted. "We bring scientists with common interests together and we show them how much they can benefit by being together, not only in terms of money and investment, but also in sharing scientific results," she said. "It's about leveraging what we [Canada] have to make it bigger, quicker."

During the first year of a two-phase collaboration, the Canadian and Dutch organizations will each spend about $\mathrm{C} \$ 100,000$ [US\$64,000] to bring scientists together to discuss potential projects, according to Perrault, with the first meeting scheduled to take place in December in the Netherlands.

Phase two will begin in about one year and will include choosing between one and three large-scale genomics programs to fund, with each country contributing about C $\$ 10$ million [US\$6.4 million] per project. Although no specific projects have been earmarked, one area of prime interest is potato and tomato genomics - finding pesticide-resistance genes as well as those that will enhance the nutritional quality of these foods - according to Marc LePage, executive vice president for corporate development at Genome Canada. The Dutch are already doing a lot of work on this, said LePage. "They will either collaborate or compete. We hope it's the former."

Genome Canada is a non-profit organization that supports genomics and proteomics research across Canada. The group is just two years old and has already funded 56 national projects totaling nearly C \$300 million [US\$192 million]. "We now have the domestic scene covered, and we have something to bring to the international table, LePage told The Scientist.

Genome Canada's deal with the Dutch is the organization's third such alliance. In 2001, the group entered a similar arrangement with Sweden, and in early 2002 another partnership was created with Spain. Two joint projects with Sweden have already been funded and begun, involving Quebec's University of Sherbrooke, the University of British Columbia in Vancouver, and counterparts at the Karolinska Institute in Stockholm. The projects involve working with Caenorhabditis elegansknock-out worms to identify genes and their function, and data will be shared with others through a large repository.

"We are going after countries that have similar interests in genomics as Canada, especially in forestry, fisheries, and some health issues," said Perrault. The Netherlands has just started its genomics program and has shown a big interest in how Genome Canada is structured and they would like to apply the same principles in their own country, she added. Perrault said that Denmark is next on Canada's alliance list. 


\section{References}

1. Genome Canada, [http://www.genomecanada.ca/select.asp]

2. Netherlands Genomics Initiative, [http://www.genomics.nl/international.htm]

3. University of Sherbrooke, [http://www.usherbrooke.ca/]

4. University of British Columbia, [http://www.ubc.ca/]

5. Karolinska Institute, [http://info.ki.se/index_en.html] 